\title{
Efek Perendaman Air Biasa dan Air Garam Sampel Pintu Air Komposit Otomatis Terhadap Sifat Mekanik Bending dan Kekerasan
}

\section{The Effect of Immersion Ordinary Water and Salt Water To Mechanical Properties Flex- ural and Hardness of Automatic Composites Water Gate Sample}

\author{
Singgih Prabowo*, Yurohman \\ Balai Teknologi Polimer, Badan Pengkajian dan Penerapan Teknologi, Kawasan Puspiptek, \\ Tangerang Selatan, 15314 \\ *Surel: singgih.prabowo@bppt.go.id
}

INFO ARTIKEL

Diterima 30 Maret 2020

Direvisi 13 Mei 2020

Disetujui 13 Juli 2020

Nomor Artikel 202103

Halaman 19-21

\section{Kata kunci:}

komposit

pintu air

perendaman
Abstract

The Unsaturated Polyester Glass Fiber composite was chosen as an automatic composite water gate material because it has plastic properties that are resistant to water and sufficient strength as a water-retaining structure. This study aims to determine the effect of ordinary water and salt water immersion on the mechanical properties flexural and hardness to automatic composite water gate sample during 360, 720 and 1080 hours compared without immersion. The test results found a decrease in mechanical properties flexural and hardness both due to immersion in ordinary water and salt water over the duration of immersion. The decrease in mechanical properties is possible due to the diffusion of water into the composite sluice sample which causes the interfacial bonding of the matrix to become weak as indicated by the addition of sample weight.

Keywords: Composite, water gate, immersion

\begin{abstract}
Abstrak
Komposit UP-FG dipilih sebagai bahan penyusun pintu air komposit otomatis karena memiliki sifat plastik yang tahan terhadap air dan kekuatan yang cukup sebagai struktur penahan air. Penelitian ini bertujuan untuk mengetahui efek dari perendaman air biasa dan air garam terhadap sifat mekanik bending dan kekerasan pintu air otomatis selama rentang waktu 360, 720 dan 1080 jam dibandingkan tanpa perendaman. Hasil pengujian didapatkan penurunan sifat mekanik bending dan kekerasan baik akibat perendaman air biasa maupun air garam seiring lamanya waktu perendaman. Penurunan sifat mekanik dimungkinkan akibat terdifusinya air kedalam sampel pintu air komposit yang menyebabkan ikatan interfacial serat matrik menjdi lemah yang ditandai dengan penambahan berat sampel.
\end{abstract}




\section{PENDAHULUAN}

Pintu air komposit otomatis dibuat dari bahan plastik yaitu Unsaturated Poyiester (UP) dengan fiberglass sebagai reinforcement nya. Bahan plastik UP dipilih karena daerah operasi pintu air banyak berhubungan dengan air oleh karena itu sifat anti karat sangat ditekankan agar memiliki masa pemakaian yang lama dan proses fabrikasi dapat dilakukan degan mudah. Komposit Unsaturated polyester (UP) fiberglass merupakan komposit yang paling luas pemanfaatannya karena memiliki harga yang murah, prosesnya mudah, dan memiliki keseimbangan yang baik antara sifat mekanik, elektrik, dan sifat kimianya ${ }^{[1]}$, komposit fiberglass mimiliki kekuatan yang cukup sebagai struktur penahan air karena komposit fiberglass sudah banyak digunakan sebagai bahan penyusun lambung kapal. Pada lapisan terluar pintu air diberi lapisan gelcoat. Gelcoat berfungsi untuk memberikan bentuk dan penampakan permukaan hasil yang maksimal pada lapisan luar pintu air. Selain itu gelcoat juga bersifat tahan korosi, tahan cuaca dan reaksi kimia karena berfungsi seperti cat pada dinding.

Ada beberapa macam proses yang telah dilakukan dalam pembuatan komposit, seperti hand lay-up, vacuum bagging dan vacuum infusion [2,3,4]. Hand lay-up merupakan teknik pembuatan yang paling sering digunakan. Menurut Clyne dan Jones (2001), ikatan interfacial antara serat dan matriks merupakan unsur yang sangat penting dalam mencapai sifat mekanik komposit yang baik. Kekuatan interface sangat berpengaruh terhadap sifat- sifat mekanik komposit, dimana interface lemah menyebabkan komposit mudah rusak. Ikatan interfacial antara serat dan matrik dipengaruhi oleh moisture absorption dan wettability (keterbasahan) dimana debonding dapat terjadi dengan mudah apabila serat memiliki moisture absorption yang tinggi, wettability yang jelek dan daya ikat yang kurang antara serat dan matrik polimer [5]. Oleh karena itu perlu dilakukan penelitian mengenai seberapa besar pengaruh perendaman terhadap pintu air komposit otomatis.

Penelitian efek perendaman air biasa dan air garam terhadap sampel pintu air komposit otomatis ini dilakukan dengan metode pembuatan hand lay-up dan diberi perlakuan perendaman air biasa dan air garam dengan konsentrasi garam 50 gr/lt. Perubahan sifat mekanik sampel dilihat dari perubahan nilai kekuatan bending dan kekerasannya setelah diberi perlakuan masing-masing selama 360, 720 dan 1080 jam dibandingkan pada saat awal sebelum perendaman $(0$ jam).

\section{METODE PERCOBAAN}

\section{Bahan}

Bahan yang digunakan dalam penelitian ini adalah tooling gelcoat (Yukalac GM-888 Red Ex) sebagai lapisan luar, Unsaturated polyester (Yukalac 150
HRN-EX) sebagai matrik, fiberglass dengan jenis chopped starnd mat (CSM) sebagai filler dan Methyl Ethyl Ketone Peroxide (MEKPO) sebagai inisiator mempercepat waktu curing, semua bahan diproduksi oleh PT. Justus Sakti Raya.

\section{Pembuatan Sampel Komposit}

Proses pembuatan komposit fiberglass pintu air ini dengan metode hand lay-up diatas flat mold, Gelcoat di hand lay-up untuk lapisan pertama setebal kurang lebih $1 \mathrm{~mm}$ tunggu sampai mengeras lalu UP-FG sebanyak 20 lembar di hand lay-up pada lapisan kedua, dengan perbandingan UP dan fiberglass adalah 1 : 2 lalu didiamkan selama 1 hari. Selanjutnya dilakukan pemotongan spesimen sesuai dengan standar pengujian bending ASTM D790 dan kekerasan ISO 2039-1, fiber yang terbuka akibat potongan dilapisi lagi dengan gelcoat.

\section{Pengujian Komposit}

Pengujian kekerasan dilakukan untuk mengetahui kekerasan sampel pintu air menggunankan metode ball indentation dengan standard pengujian ISO 2039-1. Pengujian bending dilakukan untuk mengetahui kekuatan sampel pintu air terhadap pembebanan tekan menggunakan Universal Testing Machine Shimadzu (UTM) dengan metoda 3 titik bending, ukuran spesimen panjang (16 x ketebalan) $+10 \%$ dengan lebar $25 \mathrm{~mm}$.

Perendaman air biasa dengan $\mathrm{PH}=7$ dilakukan untuk mengetahui ketahanan sampel terhadap perendaman air biasa dengan suhu ruang. Dan Perendaman air garam dilakukan untuk mengetahui ketahanan sampel terhadap air garam dengan konsentrasi garam $50 \mathrm{gr} / \mathrm{lt}$ pada suhu ruang. Setelah perlakuan sampel diambil data untuk di uji kekerasan dan bending dalam rentang waktu pada Tabel 1 .

Tabel 1. Waktu pengambilan sampel

\begin{tabular}{cccll}
\hline No & Perlakuan & $\begin{array}{c}\text { Durasi } \\
\text { (jam) }\end{array}$ & \multicolumn{2}{c}{ Pengujian } \\
\hline 1 & & 0 & Hardness & Flexural \\
\cline { 2 - 5 } 2 & Tanpa & 0 & Hardness & Flexural \\
3 & Perendaman & 360 & Hardness & Flexural \\
\cline { 3 - 5 } 4 & Air Biasa & 1080 & Hardness & Flexural \\
\cline { 3 - 5 } 5 & \multirow{2}{*}{ Perendaman } & 360 & Hardness & Flexural \\
\cline { 3 - 5 } 6 & Air Garam & 720 & Hardness & Flexural \\
\cline { 3 - 5 } 7 & & 1080 & Hardness & Flexural \\
\hline
\end{tabular}

\section{HASIL DAN PEMBAHASAN}

Pada penelitian ini didapatkan sifat mekanik bending dan kekerasan sampel pintu air otomatis mengalami penurunan akibat perendaman baik air biasa maupun air garam seiiring lamanya waktu perendaman. (Tabel $2 \& 3$ ) 
Tabel 2. Hasil pengujian hardness

\begin{tabular}{cccc}
\hline No & Perlakuan & $\begin{array}{c}\text { Durasi } \\
(\text { jam })\end{array}$ & Hardness $\left(\mathbf{N} / \mathbf{m m}^{2}\right)$ \\
\hline 1 & Tanpa & 0 & $248.00 \pm 23.46$ \\
\cline { 2 - 4 } 2 & Perendaman & 360 & $208.50 \pm 29.13$ \\
\cline { 3 - 4 } 3 & Air Biasa & 720 & $204.90 \pm 14.47$ \\
\cline { 3 - 4 } 4 & & 1080 & $201.00 \pm 14.45$ \\
5 & \multirow{2}{*}{ Perendaman } & 360 & $219.90 \pm 9.18$ \\
\cline { 3 - 4 } 6 & Air Garam & 720 & $213.90 \pm 12.52$ \\
\cline { 3 - 4 } 7 & & 1080 & $211.40 \pm 24.91$ \\
\hline
\end{tabular}

Tabel 3. Hasil pengujian flexural

\begin{tabular}{|c|c|c|c|c|}
\hline \multirow[b]{2}{*}{ No } & \multirow[b]{2}{*}{ Perlakuan } & \multirow{2}{*}{$\begin{array}{c}\text { Durasi } \\
\text { (jam) }\end{array}$} & \multicolumn{2}{|c|}{ Flexural } \\
\hline & & & $\begin{array}{c}\text { Modulus } \\
\text { (GPa) }\end{array}$ & $\begin{array}{c}\text { Strength } \\
(\mathrm{MPa})\end{array}$ \\
\hline 1 & Tanpa & 0 & $8.96 \pm 0.61$ & $199.53 \pm 8.92$ \\
\hline 2 & \multirow{3}{*}{$\begin{array}{c}\text { Perendaman } \\
\text { Air Biasa }\end{array}$} & 360 & $8.50 \pm 0.31$ & $174.63 \pm 2.95$ \\
\hline 3 & & 720 & $8.02 \pm 0.47$ & $172.89 \pm 15.02$ \\
\hline 4 & & 1080 & $7.49 \pm 0.42$ & $162.44 \pm 6.91$ \\
\hline 5 & \multirow{3}{*}{$\begin{array}{c}\text { Perendaman } \\
\text { Air Garam }\end{array}$} & 360 & $8.85 \pm 0.09$ & $194.95 \pm 12.86$ \\
\hline 6 & & 720 & $8.82 \pm 0.49$ & $178.11 \pm 10.95$ \\
\hline 7 & & 1080 & $8.81 \pm 0.87$ & $161.02 \pm 2.39$ \\
\hline
\end{tabular}

Tabel 4. Hasil pengukuran berat sampel

\begin{tabular}{|c|c|c|c|c|c|}
\hline No & Perlakuan & $\begin{array}{l}\text { Durasi } \\
\text { (jam) }\end{array}$ & $\begin{array}{c}\text { Berat Sebe- } \\
\text { lum (gr) }\end{array}$ & $\begin{array}{c}\text { Berat } \\
\text { Sesudah(gr) }\end{array}$ & $\begin{array}{l}\text { Kenaikan } \\
\text { Berat }(\%)\end{array}$ \\
\hline 1 & \multirow{3}{*}{$\begin{array}{c}\text { Perendaman } \\
\text { Air Biasa }\end{array}$} & 360 & $68.23 \pm 1.74$ & $68.45 \pm 1.78$ & $0.32 \pm 0.10$ \\
\hline 2 & & 720 & $74.20 \pm 1.33$ & $74.45 \pm 1.32$ & $0.33 \pm 0.04$ \\
\hline 3 & & 1080 & $73.83 \pm 6.63$ & $74.16 \pm 1.32$ & $0.45 \pm 0.04$ \\
\hline 4 & \multirow{3}{*}{$\begin{array}{l}\text { Perendaman } \\
\text { Air Garam }\end{array}$} & 360 & $71.59 \pm 1.39$ & $71.78 \pm 1.39$ & $0.26 \pm 0.03$ \\
\hline 5 & & 720 & $71.36 \pm 1.93$ & $71.67 \pm 1.93$ & $0.42 \pm 0.05$ \\
\hline 6 & & 1080 & $72.04 \pm 2.58$ & $72.37 \pm 2.56$ & $0.46 \pm 0.17$ \\
\hline
\end{tabular}

Dari Tabel 2. hasil pengujian didapatkan kekerasan terendah adalah $201.00 \mathrm{~N} / \mathrm{mm}$ turun sebesar $18.95 \%$ dari awal $248 \mathrm{~N} / \mathrm{mm}^{2}$ akibat dari perendaman air biasa selama 1080 jam. Tabel 3 menunjukkan modulus bending terendah adalah $8.02 \mathrm{GPa}$ atau turun sebesar $10.49 \%$ dari awal 8.96 GPa akibat dari perendaman air biasa selama 1080 jam. Kekuatan bending terendah adalah 161.02 MPa atau turun sebesar $19.30 \%$ dari awal $199.53 \mathrm{MPa}$ akibat dari perendaman air garam selama 1080 jam. Sifat mekanik pintu air komposit otomatis akibat perendaman dengan air biasa maupun air garam terjadi penurunan seiring lama waktu perendaman. Hal ini menggambarkan bahwa lingkungan air dapat menyebabkan menurunnya sifat mekanik akibat terdifusinya air ke dalam komposit [5,6,10], terlihat pada penambahan berat sampel pintu air komposit Tabel 4. yang menurunkan sifat mekanik bending dan kekerasan sampel pintu air komposit.

\section{KESIMPULAN}

Sifat mekanik bending dan kekerasan sampel pintu air komposit otomatis akan terus turun akibat perendaman air biasa dan air garam seiring lamanya waktu perendaman. Nilai kekerasan terendah adalah 201 $\mathrm{N} / \mathrm{mm}^{2}$ dan modulus bending terendah adalah 8.02 GPa didapatkan akibat perlakuan perendaman air biasa selama 1080 jam dan nilai kekuatan bending terendah adalah 161.02 MPa disebabkan perendaman air garam selama 1080 jam. Untuk mengurangi penurunan sifat mekanik bending dan kekerasan pada sampel pintu air komposit diperlukan penelitian lebih lanjut tentang efektifitas penggunaan gelcoat untuk mencegah terdifusinya air kedalam sampel.

\section{UCAPAN TERIMAKASIH}

Terima kasih kepada Balai Teknlogi Polimer BPPT yang telah mendukung dalam hal sarana dan fasilitas sehingga tulisan ini dapat terselesaikan.

\section{DAFTAR PUSTAKA}

[1] C.Liu, W.Lei, Z.cai, J.Chen, L.Hu, Y.Dai, Y.Zhou. "Industrial Crops and Products". Use of tung oil as a reactive toughening agent in dicyclopentadiene-terminated unsaturated polyester resins, Vol. 49, pp 412-418, August 2013.

[2] T. Kikuci, T. Koyanagi, H. Hamada, A. Nakai, Y. Takai, A. Goto, Y. Fuji, C. Narita, A. Endo, T. Koshino. "Biomechanics Investigation of Skillful Technician in Hand lay-up Fabrication Method". ASME 2012 International Mechanical Engineering Congress and Exposition, 2012, pp $533-539$.

[3] F.Y.C Boey, S.W.Lye. "Composite". Void Reduction in Autoclave Processing of Thermoset Composites. Vol. 23, pp 261 -265, July 1992.

[4] K. van Rijswijk, J.J.E. Teuwen, H.E.N. Bersee, A. Beukers. (2009). "Composite". Textile fiberreinforced anionic polyamide- 6 composites. Vol. 40, pp 1-10, January 2009.

[5] Wang B., Panigrahi S., Tabil., Crerar W.J., Kolybaba M., dan Sokhansanj S. (2002). Flax Fiber-Reinforced Thermoplastic Composites, Canada.

[6] Clyne, T. W., Jones F. R.,2001, Composites Interfaces, an Encyclopaedia of Materials, Elsevier.

[7] ASTM D 790-17, Standard Test Methods for Flexural Properties of Unreinforced and Reinforced Plastic Electrical Insulating Materials, West Conshohocken, 2017.

[8] ISO 2039-1-2001(en) Plastics, Determination of Hardness- Part1 : Ball Indentation Method, Switzerrland 2001.

[9] ASTM D 570-98(2018), Standard Test Methods for Water Absorption of Plastic Electrical Insulating Materials, West Conshohocken, 2018.

[10] Abdel Hamid Ismail Mourad, Amir Hussain Idrisi, Maria Christina Wrage dan Beckry Mohamed Abdel Magid, (2019,July). "Long-term durability of thermoset composites in seawater environment". Elsevier. Vol.168, pp 243-253. Belanda., UAE. 